\title{
The Role of Universities in the Modern World
}

\author{
Elena Savicheva \\ Department of Theory and History of International \\ Relations \\ Faculty of Humanities and Social Sciences \\ Peoples' Friendship University of Russia (RUDN \\ University) \\ Miklukho-Maklay St., 10/2, Moscow, Russia, 117198 \\ E-mail: savicheva@mail.ru
}

\author{
Olga Chesnokova \\ Department of Foreign Languages \\ Faculty of Philology \\ Peoples' Friendship University of Russia (RUDN \\ University) \\ Miklukho-Maklay St., 10/2, Moscow, Russia, 117198 \\ E-mail: tchesnokova_olga@mail.ru
}

\begin{abstract}
The article defines the role of university in modern society, considers its place and functions in socioeconomic and cultural development, as well as in foreign policy. The authors state that in all historical epochs the university better than other social institutions has accumulated scientific knowledge, without which a consistent development of society is impossible. It is noted that the modern era is characterized by unprecedented dynamism and rates of development. The role of information and synthesis of various cultural systems is growing. Against this backdrop, education traditionally remains a weighty lever of influence on the evolution of society, transmits the entire positive experience of the mankind to new generations. The activities of national universities are one of the elements of international politics. The article examines the concepts of Russian and foreign scholars regarding the mission and tasks of the University as a social institution. Particular attention is paid to Russia's experience in this field.
\end{abstract}

Keywords-university; education; science; society; modernization; public diplomacy

\section{INTRODUCTION}

Universities are a key component of national education systems. Scientific and technological progress, rapid development of new technologies facilitate the acquisition by education of strategic importance in the modern world. The educational level of population, its compliance with modern international standards determines the competitiveness of any state, and practically in all areas. Education is becoming one of the most important factors that ensure economic progress, social stability in the society, high standard of living. It determines the place of a state in the globalizing labor market and the international arena as well.

Nowadays Universities are increasingly involved in public-diplomatic activities. As non-state actors, they are increasingly influencing international relations and world politics.

\section{CHANGE IN THE ROLE OF UNIVERSITIES IN THE MODERN SOCIETY}

A variety of trends and processes in the modern world have been crushing global system parameters. Nowadays globalization continues to affect all spheres of human activities, including education. Any state that pretends to take a worthy place in the modern international system should be able to maintain and develop its own national educational and research systems so that they can conduct important applied research and train specialists in high demand.

In the era of globalization, it is impossible to create closed systems and models, whether it is politics, economics, culture, science or education. Today, the most promising educational models are based on joint work in projects based on mutually recognized norms and rules. The lack of innovations in education constitutes a real threat of stagnation to a country.

Today we can speak about the revised role of universities which are considered as organizations that create, store and transfer knowledge that has a special significance in the era of knowledge-based economy. Universities are able to project the outlines of the most probable future developments, formulate strategic goals in accordance with the interests of a state and its people.

It is necessary to note the special role of universities in the modern society in the formation of the socio-economic and foreign policy strategy of states. Higher education is a kind of marker for the level of development of the state and society. The most important content and status indicator of a modern university is the intensity of scientific research [Kuzmina N.B., 2014].

\section{UNIVERSITIES AS SUBJECTS OF PUBLIC DIPLOMACY}

Another important function of universities is that they act as subjects of public diplomacy, which is part of the strategy of "soft power" in foreign policy of any state. One of the features of the modern system of international relations is the activities of non-state actors on the international scene [Renalda B. (Ed.) 2011]. Their activities have intensified recently and involved a large number of people in international interaction [Lebedeva M.M., 2013]. Non-state actors, although acting independently, are called upon to support their states. Acting in the interests of their states, non-state actors including universities participate in the implementation of the "soft power" strategy. State structures 
have mainly coordinating functions, and the content of public-diplomatic activities remains with universities.

Public diplomacy of universities is focused on the target audience abroad, which includes entrants and students, university professors, representatives of political and economic elite, journalists and the public concerned. It contributes to the growth of the international political influence of the state.

Education has become a priority of strategic agenda for humanitarian cooperation between states. Non-state actors including universities form various types of partnership with each other. For instance, Russia and China cooperate in the area of education both in bilateral formats and through international organizations (UNESCO, APEC Education Foundation, Shaghai Cooperation Organization - SCO and others). The SCO's Intergovernmental Agreement on Educational Cooperation, signed in 2006, declares that " The concept of creating a single Eurasian educational entity as part of global education has become increasingly appealing from academic, social and geopolitical perspectives'[SCO's Intergovernmental Agreement on Educational Cooperation, 2006]. In October 2013 the heads of two governments signed the Memorandum of Understanding between the Ministry of Education and Science of the Russian Federation and the Ministry of Education of China on Cooperation to Create Specialised University Association of Russia and China.

A distinctive feature of modern development nowadays is the process of transitioning from bilateral cooperation in realization of specific educational or research programs between individual universities towards multilateral interaction among consortiums of universities on a wide range of issues and topics [Internationalization of Russian Universities, 2014, P. 50] . In this context we can mention such multilateral consortiums as Association of Pacific Rim Universities that unites more than 40 leading research universities from 16 countries; BRICS League of Universities (2013); consortium of SCO's Universities (more than 50 members). The universities-partners try to identify key areas for joint educational and scientific projects.

Over the past several years, this tendency has begun to affect Russia's activities in educational and scientific fields. The following Russian associations - The Association of Leading Russian Universities (founded in 2010, unites about 40 universities), The Association of the Leading Universities in Economics and Management (founded in 2012, unites about 20 universities) could serve as actors in this process. Another example - the powerful ties of the Peoples' Friendship University of Russia (RUDN University) with the universities of the CIS countries contributed to creation of the CIS Network University on its basis.

Experts identify such mechanisms of universities' influence on the international sphere as: training of the professional elite, participation in international scientific and information campaigns, formation of discourses, media resources, web technologies, content of university libraries, etc.
Universities form a global elite, i.e. people who have an in-depth insight into the global and national problems and can offer solutions to them. It is universities, that in the framework of their educational and scientific activities play an important role in the formation of the world economic and political elite. The potential of universities in shaping the world elite is to a certain extent assessed through the identification of the number of foreign students. For example, students from more than 140 countries of the world study in the Peoples' Friendship University of Russia that has been functioning in Moscow since 1960. This is the only scientific institution in the world in which representatives of more than half of the countries of the world are trained. Its graduates work in 170 countries, where they often occupy leading positions in science, business and politics.

The opening of branches and campuses abroad also works for this purpose - the formation of the elite that knows Russia and is open for further cooperation.

Universities not only train highly qualified professionals, but also host or delegate their students and post-graduate students to international events - forums, conferences, exhibitions, etc., thereby entice young people from the student's bench to work at the international level, involve them in the process of impact on public opinion in different countries.

Universities have become venues for meetings with student audiences for political leaders - foreign heads of state and heads of government. As a rule, such visits are made to certain universities and have a symbolic character. In this sense, the most illustrative example is the Russian university - MGIMO (Moscow State Institute of International Relations), which is the main forge of diplomatic personnel in the country. MGIMO provides its platform for speaking to foreign leaders in the framework of public diplomacy. Such meetings between the heads of states and foreign affairs agencies, ambassadors, representatives of the diplomatic corps with the student audience have an informal nature and differ from official press conferences held at the final stage of traditional international negotiations.

The rector of MGIMO notes in one of his speeches that communication of students of his University with such political figures as Clinton, Shirak, Mubarak, Kissinger, Aliyev, etc. is of great importance for the formation of the future international specialists [Torkunov A., 2010. P.456457].

It has become a good tradition to create associations of graduates of higher educational institutions, as a result, even after graduation, many university graduates do not lose contact with those with whom they studied.

Discursive resources of public diplomacy of universities are mainly associated with the publication activity of university staff and the level of citing their publications. Currently the level of citation of researchers is the most important indicator determining the place of the university in the global competitive space of higher education. 


\section{THE CASE OF RUSSIA}

As for Russia - universities are considered there to be a strategic resource of the country. Creating world-grade universities is a new trend in Russian higher education. Scientific research and teaching process are equals on their premises: they develop and supplement each other. A strategic goal of contemporary development of the Russian higher school is to make universities a full-value and equal members of the world university community. This trend is supported with the state policy on higher education. It requires not only tangible investments but also modernization of the existing educational and scientific programs.

The Russian education system is one of the most reformed areas in the post-Soviet period, even against the background of large-scale reforms that have affected other spheres of the society.

An ambitious task of creating at least five to ten worldgrade universities listed in the top 100 of international ratings has been set for Russian higher school. The number of different ratings is increasing at the present time, and currently the most famous are the ratings of QS-THES, Shanghai, Webometrics, Reuters. These ratings are different. Accordingly, various places are occupied by the universities of Russia.

The positioning of universities in international rankings also has a political dimension, as it can be used to enhance the prestige of the state, to promote its positive image in the international arena.

The universities in Russia have become members of public-diplomatic structures. For example, a number of Russian universities, including the Moscow State Institute of International Relations (MGIMO), the St. Petersburg State University, the Russian State University for the Humanities and some other are members of the Russian Council for International Affairs.

Significant attention is now being paid to the creation of think tanks at universities that conduct political research, create industry expertise, which can be used in making government decisions [Kuzmina N.B., 2014, P.82-83].

The authors of the article believe that University in Russia has much more significance in the society than in the West states. In the country, which is distinguished by the diversity of the ethnic and confessional composition of its population, large number of languages, the level and character of the economic life, the University also performs an important civilizational function. It unites the Russian society, creates a single cultural field, on the basis of which only there can be a strong state organism. Therefore, the University is one of the main pillars of Russian statehood.

\section{CONCLUSION}

We emphasized a special role of universities in the modern society, their significance in the formation of the socio-economic and foreign policy strategy of states.
Universities should become more dynamic, flexible, sensitive to social, scientific, technical and technological challenges, since they are involved in innovation and international competition. In a dynamic environment, the renewal of the university must be continuous.

Today, in the context of globalization, the importance of the university's activities in the international arena is growing. Universities are dealing with a qualitatively new stage of international cooperation, characterized by the growing pace and depth of interaction between national educational systems, the creation in some regions of conditions for their integration and the gradual formation of an integral world educational space.

The increasingly strong public opinion that education, science and universities are forging the future of humanity is not accidental.

\section{REFERENCES}

[1] Internationalization of Russian Universities: the Chinese Vector. Russian International Affairs Council. - 2014. № 13.

[2] Kuzmina N.B. Effective University: reboot. - M., 2014 (in Russian).

[3] Lebedeva M.M. Actors of Contemporary World Politics: Trends of Development. // Journal of MGIMO University. - № 1(1), 2013.P.6876.

[4] SCO's Intergovernmental Agreement on Educational Cooperation (signed in Shanghai on June15, 2006). URL:http://www.conventions.ru/view_base.php?id=1497(in Russian)

[5] Torkunov A.V. On the way to the future Moscow, 2010 (in Russian).

[6] Renalda B. (Ed.) The Ashgate Research Companion to Non-State Actors. - Burlington: Ashgate, 2011. 